Final approved version of manuscript published in 2017 in Energy Policy. For final published manuscript, please see: $\underline{\text { http://dx.doi.org/10.1016/j.enpol.2017.04.013 }}$

\title{
Sine Qua Nons of Sustainable Biofuels: Distilling Implications of Under-Performance for National Biofuel Programs
}

\author{
Laura German, Ariane Goetz, Tim Searchinger, Gustavo de L.T. Oliveira, \\ Julia Tomei, Carol Hunsberger and Jes Weigelt
}

\begin{abstract}
Biofuels have been promoted worldwide under the assumption that they can support several strategic policy goals, while mitigating associated risks. Drawing on published evidence on performance, contributing papers to this Special Section question assumptions commonly attributed to biofuels: their carbon neutrality, their positive effect on rural livelihoods, and policymakers' ability to effectively govern for sustainability. This paper takes these findings as its starting point and asks, "What next?" for countries wishing to advance biofuels as one option for the necessary divestment from fossil fuels. Deriving recommendations for national biofuel programmes from past performance is no easy task. Context, complexity, power dynamics and scaling pose significant challenges to achieving policy aims. We are nevertheless able to distil a set of sine qua nons (indispensables) for sustainable biofuel governance from the evidence and change management literatures. They are put forward not as recipes for success, but minimum conditions and "best bet" approaches requiring testing, deliberation, and refinement. Perhaps the most fundamental sine qua non is to pursue options that downscale global demand - as current levels of global energy consumption, if only in the transport sector, cannot be met by biomass-derived agrofuels in a way that meets social and environmental sustainability goals.
\end{abstract}

Keywords: Biofuels; agrofuels; sustainability governance; energy policy

\section{INTRODUCTION}

Ambitious renewable energy targets are being established by nation states and international institutions, from the International Panel on Climate Change to the 2030 Agenda for Sustainable Development. Biofuels feature prominently in many national energy and climate mitigation plans, including the EU Renewable Energy Directive (EU-RED), Nationally Determined Contributions to the Paris Agreement, and companion national energy policies and plans. ${ }^{\text {T This }}$ continued faith in biofuels contrasts with their patchy performance to date. While enthusiasm for first generation biofuels may have diminished, expectations remain high about the potential of advanced biofuels and the use of biofuels in hard-to-decarbonise sectors such as aviation. Experiences with first generation biofuels have highlighted the interdependencies between the multiple end-uses of biofuel feedstocks (i.e. for food, feed, fibre and fuel) and the multifunctionality of land.

The aims of this concluding paper are twofold: to re-visit and expand the findings from the Special Section's contributing papers and recent policy debates on biofuel performance to date, so as to distill lessons learnt; and to draw on these lessons and the wider literature on change management and scalability to explore implications for biofuel governance. The outcome is an 
Final approved version of manuscript published in 2017 in Energy Policy. For final published manuscript, please see: http://dx.doi.org/10.1016/i.enpol.2017.04.013

ambitious effort to identify sine qua nons in biofuel governance for sustainability. Given what we know about the complexity of social and ecological systems; the importance of values and context in undermining the promise of one-size-fits-all solutions; the tendency of national sustainability governance to externalize sustainability problems through "the market"; and the role of human agency at all levels in undermining the determinacy of program outcomes, these "indispensables" are not suggested as recipes for success. It is suggested, rather, that without these essential steps biofuel programs are likely to fail both in their purported aims (e.g. net GHG benefits, energy security, rural development) and in other fundamental dimensions of sustainability (e.g. minimal harm to local ecosystems, respect for basic human rights). Furthermore, adherence to these sine qua nons alongside a knowledge-intensive, adaptive approach to change management can help bring performance more in line with official policy aims while detecting critical risks before they lead to premature failure or unacceptable costs. In theoretical terms, it can help bring sociotechnical imaginaries (Jasanoff and Kim 2009) surrounding biofuels more in line with what is actually achievable in light of not only their technical feasibility, but their social acceptability given alternative interests and values (see, for example, Eaton et al. 2014). It might be said that the idealized nature of identified sine qua nons are themselves imaginaries of a more procedural nature. While true, we see value in establishing a methodological roadmap for more informs and pluralist policy action, as well as a standard against which national policy processes and the chosen use of public funding within these processes (e.g. implementation vs. analysis, piloting and public engagement) may be evaluated.

The section that follows reviews theoretical perspectives on change management, profiling the challenges of managing uncertainty in policy interventions and of taking successful pilot experiences to scale. Section III summarizes the evidence derived from contributing papers of the special issue and the wider literature on biofuel sustainability, so as to distill a set of lessons for policy makers. We then draw on this theory and evidence in Section IV to distill sine qua nons for biofuel governance.

\section{THEORIES OF CHANGE: MANAGERIAL INSIGHTS FOR NATIONAL BIOFUEL PROGRAMS}

This section reviews the literature on change management and scaling up for insights into factors that contribute to divergence between policy and program aims and actual outcomes, and factors that underlie successful change management.

\subsection{The Science of Scaling}

In the context of biofuels, scale is primarily understood as geographical scale, "the spatial dimensions of a process (...), or a decision" (Wilbanks 2007: 279). The sustainability of efforts to upscale biofuel production and consumption depends on the impacts of several distinct yet interrelated components of (up)scaling: expansion of project size; expansion of the total land area devoted to bioenergy production; and expansion of other input factors in the production process (e.g., seeds, labour) (Mohr and Raman, 2013; Tilman et al., 2002; Hunsberger et al., this issue; Buchholz \& Volk, 2012; Goetz et al., this issue; Ekins, 1993). Moreover, due to technological innovations (e.g., internet, transport), the distance between biofuel production 
Final approved version of manuscript published in 2017 in Energy Policy. For final published manuscript, please see: http://dx.doi.org/10.1016/j.enpol.2017.04.013

and consumption has grown: countries that are net consumers of biofuels increasingly incorporate other countries' and regions' lands and biomass production in their strategies to meet national biofuel mandates through imports (Wilbanks, 2007). The perspective of spatial scales underlines the necessity of assessing biofuels production and consumption in the context of wider socio-economic and ecological system boundaries in which it takes place - to identify unintended consequences of local choices on the regional and global level (and vice versa), and determine corresponding responsibilities and accountabilities (Buchholz \& Volk, 2012; Wilbanks, 2007; Goetz et al, this issue; Dale et al., 2010). Often confounded with this understanding are three other types of scale that matter for assessing sustainability: the scale of organizational structures (e.g., small-holder production vs. large-scale plantations); versatile vs. singular feedstock infrastructure (shaping flexibility in responding to market fluctuations and sustainability concerns); and temporal scales (e.g., long-term or short-term planning, late- vs. early return of investment made) (Buchholz \& Volk, 2012; Hunsberger et al., this issue; Goetz et al., this issue).

Expanding land demand for biofuels tends to increase pressure to intensify agricultural production, with known challenges for socio-economic and ecological sustainability ranging from soil degradation, unsustainable water use and pollution and reduction in biodiversity, to displacement and human rights violations. Related land use and land cover changes - direct and indirect - reduce the climate mitigation potential of biofuels, while competition with other land uses, such as food production, can threaten basic human securities (Tilman et al., 2002; Gallagher, 2008; Borras et al., 2010; Franco et al., 2010; Mitchell, 2010; Gasparato \& Stromberg, 2012). Nonetheless, large-scale production continues to be seen as cost competitive, profitable and amenable to state and private sector control. It also enhances the leverage of private enterprises vis-à-vis state authorities and international organizations - for instance, when negotiating tax breaks, or accessing carbon markets (Buchholz \& Volk, 2012). This means that the widespread preference for geographical upscaling runs counter to evidence-based policy making (Sutcliffe and Court, 2015; Cheng and Timilsina, 2011).

There is vast empirical evidence of the risks associated with large-scale projects and production programmes, such as those derived from the difficulty of putting large-scale projects into operation (due to high upfront costs and long payback times) or loss of flexibility for responding to challenges in a timely manner due to limited oversight from headquarters (Hawkins and Chen, 2011; Goetz, 2015; Cheng and Timilsina, 2011). In cases where agricultural programmes, including biofuels programmes, aim to expand smallholder production of a particular crop, producers face price fluctuations or other political economic hurdles. Moreover, focusing on a single feedstock can have huge environmental costs (e.g., reduction of biodiversity, use of agrochemicals) (Oliveira et al., this issue; Goetz et al., this issue).

Complexity also increases with scale and poses a challenge for decision-making. New linkages and feedbacks between different scales and types of scale (spatial, temporal, organizational) are often neither foreseeable nor known; nor are the ways in which governance measures at different scales reinforce each other, or work against each other. New actors and governance levels become implicated in finance, governance and management, as well as new lands and 
Final approved version of manuscript published in 2017 in Energy Policy. For final published manuscript, please see: http://dx.doi.org/10.1016/j.enpol.2017.04.013

ecosystems. At different spatial scales, different forms of information are available, and different solutions apply (Wilbanks, 2007). To deal with this analytical challenge, large-scale programmes tend to be built based on modelled futures and scenarios. Yet, these models and the recommendations emanating from them require a number of assumptions and simplifications, making it difficult to produce realistic policy prescriptions that can ensure sustainable production and consumption at different scales and across contexts. As a result, evidence-based policymaking is rare (Goetz et al., this issue; Searchinger, this issue). A multiscale perspective drawing on contextualized data is therefore crucial for guaranteeing biofuels' sustainability (Trent and Chavis, 2009).

\subsection{Managing Change: Trade-offs, Uncertainty, Learning}

Policy proposals tend to be framed as "win-wins": initiatives that can deliver multiple benefits to diverse constituencies. This is no less true for biofuels than other arenas such as biodiversity conservation, avoided deforestation and agricultural investment (Bergius 2012; Goetz et al, this issue; Hirsch et al., 2010). While this framing may help to leverage funding and bolster political support, it can also fuel a cycle of optimism and disenchantment as purported panaceas fail to fulfil their promise (Hirsch et al. 2010; see also Brosius \& Russell 2003; Ostrom 2007; Redford \& Adams 2009). This approach also contrasts with growing acknowledgement that value tradeoffs are inherent in multi-objective policy arenas (Keeney and Raiffa 1976), and that the consequences of any given intervention are experienced, perceived, and understood in multifaceted ways by differentially positioned actors (German 2015; Hirsch et al. 2010; McCarthy 2010).

A growing literature emphasizes the benefits of recognizing multiple environmental values and making trade-offs explicit in environmental policy and practice. In addition to the obvious conversations that a trade-off lens forces about any given policy carrying losses as well as benefits (Hirsch et al. 2010; McShane et al. 2010), acknowledging conflicting views and interests may provide a platform for deeper deliberation and negotiation of competing interests and values (Brechin et al. 2003). The hard work of reconciling competing interests and values can help to cement political support for interventions, while its absence can leave plans vulnerable by masking underlying grievances and exacerbating ideological divisions in society (German et al. 2011; German et al. 2016; Miller and Erickson 2006; Walley 2004). Doing so may also simply make agreements on how to reconcile diverse interests on any given plot of land possible (Lee 1999). Miller and Erickson (2006) take this reasoning a step further, suggesting that efforts are needed to bridge not just diverse values, but alternative epistemologies. To ensure substantive rather than symbolic inputs into decision-making, the process should be "pluralistic in embracing the necessity to communicate across difference without erasing difference; reflexive in its questioning orientation to established traditions; ... and dynamic in its openness to everchanging constraints upon and opportunities for democratization" (Dryzek 2000: 3). Recognition of epistemic pluralism and intentional deliberation across difference are for these authors crucial elements of democratic governance.

Another crucial element of change is uncertainty. Plans rarely work the way they are conceived, and even the best made plans carry an element of surprise (Colfer 2005). 
Final approved version of manuscript published in 2017 in Energy Policy. For final published manuscript, please see: http://dx.doi.org/10.1016/j.enpol.2017.04.013

Interventions having multiple objectives only magnify this uncertainty (Keeney and Raiffa 1976). Uncertainty may be due to the complexity of natural and social systems, for which even simple steps may yield unexpected outcomes (Lee 2002). It may also be due to the simplifying assumptions that underlie interventions and accompanying theories of change (Vogel 2012). Some suggest such simplification to be part and parcel of the policy process:

"Expert advice is often thought most useful to policy when it is presented as a single 'definitive' interpretation. Even when experts acknowledge uncertainty, they tend to do so in ways that reduce unknowns to measurable 'risk'... A preoccupation with assessing risk means that policy-makers are denied exposure to dissenting interpretations and the possibility of downright surprise" (Stirling 2010: 1029).

Gunderson (1999) identifies common yet inadequate approaches to dealing with uncertainty in resource management: assuming it away; seeking spurious certitude (by breaking a problem into trivial questions and policy actions that are unambiguously "correct"); or replacing uncertainty of outcomes with certainty of a process (such as a new policy or regulation, or a technical oversight committee). What these simplification tendencies mean is that "most policies are really questions masquerading as answers" (Gunderson 1999: 1). The road least followed but thought to be most effective is to confront uncertainties head-on: taking them as a given, and making feedback and learning central to policy formulation and implementation.

Adaptive collaborative management (ACM) has emerged as a leading paradigm for reconciling the value and interest disputes and pervasive ecological and social uncertainty characterizing resource management arenas (Armitage et al 2008). ACM may be defined as an "approach whereby people who have interests [in a particular policy or resource management arena] agree to act together to plan, observe, and learn from the implementation of their plans while recognizing that plans often fail to achieve their stated objectives" (Colfer 2005: 4) - or simply "implementing policies as experiments" (Lee 2002: 2, citing Holling 1978; Walters 1986). It is characterized by conscious efforts among groups to communicate, collaborate, negotiate and seek opportunities to learn collectively about the impacts of their actions (Colfer 2005: 4).

The core elements of ACM are twofold: it is adaptive in managerial perspective, and collaborative in governance (Lee 1999). Adaptive means that learning, in the form of systematic assessment and feedback, is at the core of the process, and iterative adjustments in management and policy based on this learning are central (Armitage 2008; Colfer 2005). It may also mean taking an experimental approach to policy implementation, where uncertainties are systematically tested in practice (Lee 1999). Assessment, which should focus on social and ecological outcomes as well as the implementation process itself (Armitage 2008), is essential to determining appropriate institutional responses to change (Bellamy et al. 2001). Feedback mechanisms from the local arena to policy makers are also crucial to understanding the nature of unanticipated consequences, and provide opportunities to learn from failure (Colfer 2005). Collaborative means that change management "is characterized by group decision making that accommodates diverse views, shared learning, and the social sources of adaptability, renewal, and transformation" (Armitage 2008: 2). Collaborative approaches to management help 
Final approved version of manuscript published in 2017 in Energy Policy. For final published manuscript, please see: http://dx.doi.org/10.1016/j.enpol.2017.04.013

advance democracy by ensuring that those affected by policy choices have a voice in policymaking, while ensuring that learning informs not just policy but also individual and collective choice at the local level (Miller and Erickson 2006; Parson and Clark 1995). The collaborative element extends to the learning process as well, by ensuring that relevant actors are involved in determining "what questions to ask, what outcomes to encourage, and the choice of indicators used to assess outcomes" (Armitage 2008: 6). Together, these core ingredients of ACM shift the emphasis from command-and-control to flexibility and innovation - key ingredients of resilience and adaptive capacity (Armitage 2008; Gunderson 1999; Pinkerton 2007)ii.

While it may be thought that the adaptive element is best suited to addressing uncertainty and the collaborative approach best suited to addressing value trade-offs, each element contributes to each of these challenges. Learning is information-intensive and requires active participation from those most likely to be affected by policies (see Margoluis and Salafsky 1998). This provides an opportunity for the learning and assessment process to incorporate the views and interests of local actors - thus advancing efforts to acknowledge and manage trade-offs. Collaboration, on the other hand, can help identify failures and unanticipated consequences early on by bringing novel frames of reference and scales, and multiple sources and types of knowledge, into management and decision-making (Armitage 2008).

While ACM is undoubtedly useful in forging a transition toward a more sustainable economy, there are reasons to query its political feasibility. Adaptive management may be an unsettling approach for those who think of management in terms of command (Lee 2002), and for whom transparency is undesirable:

"What is learned from the adaptive process reveals not only the way the ecosystem responds but also what the managers are doing, whether it works, and whose interests it serves... There are benefits from increasing understanding of the social and natural interactions. But ... there are risks of disclosure of activities which look inappropriate in the eyes of one or more stakeholders. ... When the manager is a public official, the balance between benefits and risks of learning is likely to be measured in political metrics" (Lee 2002: 7).

If ACM is to move beyond its current influence as an idea to shape how policy is conceived and implemented, an intentional approach to resolving conflicts and a transition to organizational cultures that welcome opportunities to learn from failure will be necessary (Colfer 2005; Lee 2002).

\section{DISTILLING EVIDENCE ON THE SUSTAINABILITY OF LIQUID BIOFUELS}

This section synthesizes evidence from the literature on the effectiveness and sustainability of national biofuel programs, drawing from the papers in the Special Section. While individual papers review the evidence on the specific themes, here we aim for a higher-level synthesis of findings. The evidence suggests that while some policy aspirations linked to biofuels have proven to be achievable only when narrowly defined or under particular circumstances (e.g. climate mitigation), others have remained out of reach. 
Final approved version of manuscript published in 2017 in Energy Policy. For final published manuscript, please see: $\underline{\text { http://dx.doi.org/10.1016/j.enpol.2017.04.013 }}$

\subsection{The Myth of Climate Neutrality}

Evidence suggests that climate neutrality, the primary justification for biofuels programs in many countries and in prominent consumer markets, is achievable under a far narrower range of conditions than often thought - significantly undermining their promise to deliver cleaner energy at scale without incurring other unacceptable costs (MacKay, 2009; Searchinger and Beringer, this issue; Tilman et al., 2009). Given growing demands on land for meeting other societal needs, such as food production, the world lacks the room to dedicate land to bioenergy. Even if certain areas were to be prioritized for bioenergy production, the carbon costs of dedicating land to bioenergy are likely to exceed the benefits (Searchinger and Beringer, this issue). Analyses that provide more optimistic forecasts largely rely on accounting errors that have, in various ways, counted the benefits of using land or biomass without counting the costs.

Some of the earliest concerns over these projections of biofuel's potential to mitigate climate change focused on the failure to account for carbon debts associated with land use change or to acknowledge indirect land use changes (Achten et al, 2011; Lapola et al., 2010; Plevin et al., 2010). Another accounting error, present in Kyoto Protocol rules and national cap-and-trade laws, is the failure to count $\mathrm{CO}_{2}$ emitted from tailpipes and smokestacks when bioenergy is being used, while also failing to count changes in emissions from land use when biomass for energy is harvested or grown (Searchinger et al., 2009). Failure to distinguish additional carbon from carbon already absorbed or withheld from the atmosphere presents another problem (Searchinger, 2010). The review of estimates from integrated assessment models suggesting large bioenergy potential (Searchinger and Beringer, this issue) shows that they depend on many contingencies for carbon benefits, can impose many biodiversity and food costs, and focus more on idealized than plausible future scenarios.

These errors have led to a host of damaging reports on the actual impact of renewable energy policies designed to minimize emissions. One report, for example, finds that first-generation biodiesel imported by the EU might produce on average $40 \%$ more $\mathrm{CO}_{2}$ emissions than fossil diesel (NABU and Transport and Environment, 2016). Particularly problematic is the increased use of palm oil as car fuel and input into electricity plants (Roos, 2010). According to estimates by NABU and Transport and Environment (2016), the 34\% growth in EU biodiesel since 2010 may be attributed to imported palm oil. One report estimates that for every ton of Indonesian palm oil produced, 32 tons of $\mathrm{CO}_{2}$ are emitted - which does not account for emissions from transportation and processing (Jefferson, 2013). Added to this concern are the multiple ecological and social impacts of palm oil production, such as deforestation, biodiversity and habitat loss, public health costs from burning drained peatland, and land rights violations (Danielsen et al., 2008; Goetz et al, this issue; Koh and Wilcove, 2008; Obidzinski et al., 2012). Yet some policies in Europe count palm oil as renewable energy to be promoted under their renewable energy mandates (Roos, 2010; Jefferson, 2013).

After accounting for the opportunity costs of land and biomass, the conditions under which biofuels remain viable for climate mitigation is far narrower than typically assumed (Searchinger and Beringer, this issue). These include: 1) producing bioenergy from residues and 
Final approved version of manuscript published in 2017 in Energy Policy. For final published manuscript, please see: http://dx.doi.org/10.1016/j.enpol.2017.04.013

wastes, assuming their alternative uses are properly accounted for; 2) upgrading from less efficient to more efficient bioenergy (Bruun et al., 2014), which still faces many financial and cultural barriers; and 3) using bioenergy crops to facilitate land reclamation under certain circumstances. The authors conclude that, under the present technological and governance circumstances, policies should not support bioenergy production from energy crops and other dedicated uses of land.

\subsection{The Ability of Biofuels to Reduce Reliance on Fossil Fuels}

One of the expectations for biofuels typically "bundled" with climate mitigation is the ability to enhance domestic energy security. Biofuel production and use targets have been reached in particular countries (especially Brazil, US and Thailand), advancing energy security by diversifying energy sources, reducing import dependence and saving foreign exchange (Hunsberger et al, this issue). Yet these gains are only achieved by ambitious government programs and public investment (de Oliveira this issue; Schoneveld et al, 2010), and are concentrated in the transport sector, where their contribution to global final energy consumption is limited to $0.8 \%$.

The imbalance between their minute contribution to global energy needs and the magnitude of social and environmental concerns they have raised points to the difficulty of employing biofuels as a pathway to energy security. Biophysical constraints make it unfeasible for biofuels to substitute current fossil fuel consumption levels, even in the transport sector (Searchinger, this issue). Ongoing controversies exist among practitioners and researchers about biofuels' utility for solving any energy sustainability issues - from scarcity to climate (Hickey, 2010; Mackay, 2009; Searchinger, 2010; Tilman et al., 2009; Mackay, 2009). In the words of MacKay, former Chief Scientific Adviser to the UK Department of Energy and Climate Change from 2009 to 2014, "Even leaving aside biofuels' main defects - that their production competes with food, and that the additional inputs required for farming and processing often cancel out most of the delivered energy - I think they are scarcely worth talking about" (MacKay, 2009: 44). While one might not endorse MacKay's views, there is clearly a need to advance public debate and research on how to set priorities (e.g., climate mitigation vs. agrarian justice, the risk of nuclear waste for future generations). There is also a need to build awareness and scientific capacity to evaluate the sustainability of biofuels and calculate opportunity costs of energy options, while pushing for strategies to reduce total consumption.

\subsection{Biofuels as a Pathway to Rural Development}

In addition to reducing $\mathrm{CO}_{2}$ emissions and enhancing energy security, biofuels are widely touted for their ability to foster rural development by generating employment, benefiting smallholders and supporting decentralized energy systems (EU, 2009; MME, 2007; Republic of South Africa, 2007). Employment benefits vary considerably depending on the feedstock, production stage, level of intensification, context and - importantly - the indicators chosen to evaluate it (Hunsberger et al., this issue). Employment intensity can be high for crops that are difficult to mechanize, such as cassava, jatropha and oil palm. It has also been historically high for sugarcane. However, employment intensities vary considerably within a feedstock due to 
Final approved version of manuscript published in 2017 in Energy Policy. For final published manuscript, please see: http://dx.doi.org/10.1016/j.enpol.2017.04.013

differences in scale and intensification. When a key industry grows in scale and sophistication, it becomes less labor intensive (Binswanger, 1986) - a trend which is evident in the Malaysian oil palm and Brazilian soy and sugarcane industries (Barlow et al., 2003, cited by World Bank, 2010; Bickel and Dros, 2003; Dufey, 2008; Ortiz and Rodrigues, 2006). Data comparing benefits to smallholders working their own farms (growing feedstock or mixed cropping systems) vs. working as wage laborers suggest greater employment intensities and returns to the former (Deininger et al., 2011; Li, 2011) or no detectable difference (Herrmann and Grote, 2015). This significantly discredits discourses justifying land acquisitions in the name of employment. While it is often argued that employment can offset the costs of land loss, strong and consistent evidence reveals employment biases that favor migrant workers over local residents (Colchester, 2011; Deininger et al., 2011; German et al., 2011b; Li, 2011; Obidzinski et al., 2012; Smalley, 2013; Thondhlana, 2015; World Bank, 2010). Disappointing employment benefits have been a general trend of the recent land rush (Deininger et al., 2011), and worse for feedstocks prone to technical or economic failure. It is also clear that employment does not guarantee livelihood improvements. While factory work tends to be more permanent, higher paying and more highly valued (Feintrenie et al., 2010; UNEP, 2008), most of the jobs created are in the plantation sector where job quality is usually low - often dismally low. Employees often struggle to leverage livelihood benefits from employment due to the unskilled, casual and migrant character of plantation labor; poor employment conditions; competition with other livelihood streams; and health consequences of employment (Colchester, 2011; German and Parker, 2015; Hunsberger et al, this issue; Li 2011; Macedo, 2005; World Bank, 2010).

Regarding other benefit pathways, smallholder income has been shown to have improved through the cultivation of "flex crops" in select cases (e.g. oil palm in Sumatra, Indonesia and sugarcane outgrower schemes in Africa) (Hunsberger, this issue; McKersie and Hichaambwa 2011), and isolated successes may also be found in decentralized energy systems (Hunsberger et al, this volume). However, barriers to market entry, including insecure land tenure, limited financial and natural capital and limited economies of scale, tend to limit their market share (de Andrade and Miccolis, 2011; Ariza-Montobbio and Lele, 2010; Hunsberger et al., this issue; Montefrio and Sonnenfeld, 2013). For those examples that can be held up as models of smallholder inclusion for the biofuel industry, the role of the state (as regulator and financier, and to a lesser extent capacity builder) seems paramount both in achieving and maintaining distributional equity. Even for those cases held up as models of what biofuels can deliver, success is patchy and its effects are highly uneven (German and Parker, 2015; McCarthy, 2010).

\subsection{The Myth of Minimum Harm}

Enshrined in many of the policy documents reviewed by Goetz et al. (this issue) are assumptions that the risks associated with biofuels (e.g. deforestation, food insecurity, biodiversity impacts, land rights violations) do not pertain to the country in question, or can be easily mitigated. Simple recognition of the presence of certain risks is often lacking altogether in these documents (e.g., MNRE, 2009; Caroko et al., 2011). Evidence suggests that risk rationalizations and mitigation strategies, where applied, were in many cases ineffective and did not prevent harms (e.g., Borras and Franco, 2011; Baka, 2014; Goetz, this issue). In the case of food security effects, for instance, evidence suggests that the diversion of food crops (soy, 
Final approved version of manuscript published in 2017 in Energy Policy. For final published manuscript, please see: http://dx.doi.org/10.1016/j.enpol.2017.04.013

maize) or land area towards biofuel production - as promoted under the U.S. Renewable Fuel Standard (RFS) and the European Union's Renewable Energy Directive (RED) - was one of the structural factors contributing to the $2007 / 2008$ and 2011/2012 price rise of food commodities, and is believed to be sustaining high agricultural commodity prices (Gerber et al. 2008; Goetz et al., this issue; Wise und Cole, 2015).

Any assessment of social and ecological performance also needs to account for the global repercussions of regional or national land use and consumption choices in the context of trade and investment. This is important when weighing the costs and benefits of biomass for nonfood, non-feed purposes, which can result in land use change, overuse of ecosystems and resources, human rights violations, and net export of ecosystem services (Hartemink et al., 2008; Schnoor, 2006; Léon-Moreta, 2011). Improved supply chain data shows that $38.2 \%$ of EU's total soy imports stems from Brazilian municipalities where soy production is associated with deforestation, and a significant share of soy imported in the EU could be traced to Brazilian municipalities with forced labor during 2010-2013 (Godar et al. 2016). Such trends are not restricted to global North-South relations, but also appear among industrialized nations. Forests cut in the U.S., for example, have been sold as "waste wood" for energy production in Europe (NRDC 2015). Rising demand for biofuels in industrial countries has provided incentive for those investing in developing countries to produce for distant markets, thereby externalizing to producer countries not just economic opportunity but also ecological and social costs.

\subsection{Vague and Narrowly Defined Expectations}

The metrics used to set policy targets and evaluate their outcomes are crucial. Hunsberger et al (this issue) conclude that policy aims are framed in both vague and narrow terms. The former arguably fosters divergence between the narratives of benefit and actual outcomes, between discursive and material realities. This is amply illustrated by Searchinger (this issue), who identifies multiple forms of "double counting" underlying assumptions that biofuels can provide a low- or no-carbon fuel. It is also illustrated by the disconnect between climate change mitigation and livelihood benefits as the primary discursive drivers, and energy security and industrial development as the primary outcomes of biofuel policies (de Oliveira et al. and Hunsberger et al., this issue).

Narrowly framed aims, on the other hand, open the door for positive evaluations of program effectiveness while obscuring other ways in which programs may undermine those very same aims. This may be illustrated by the variable ways in which employment and smallholder outcomes may be evaluated, and the divergent findings that emerge when adopting different metrics (Deininger et al., 2011; German and Parker 2015; Hunsberger et al., this issue; Li, 2011; McCarthy, 2010; Schoneveld et al., 2011; World Bank, 2010). If we measure success as the simple fact of jobs being created or smallholders being engaged as outgrowers, then biofuels may be viewed as a success. If, however, we consider the ability to leverage livelihood benefits within the biofuel industry, the opportunity costs associated with the reallocation of land and labor, and the social consequences of incorporation (on health, gender, freedom of choice, etc.) and the distribution of risk, then success is harder to identify (McCarthy, 2010; Obidzinski et al., 
Final approved version of manuscript published in 2017 in Energy Policy. For final published manuscript, please see: http://dx.doi.org/10.1016/j.enpol.2017.04.013

2012). Based on the review by Hunsberger et al (this issue), there is no guarantee that employment will generate greater returns to land or labor than smallholder agriculture, and there is extreme unevenness in outcomes across households within any given industry or investment (see also Deininger et al., 2011; McCarthy, 2010; Obidzinski et al., 2012; Schoneveld et al., 2011). Thus, policy documents specifying only "job creation" make policy effectiveness difficult to evaluate, or so self-evident as to be meaningless.

\subsection{Ineffective Governance - Both Public and Private}

Turning now to the papers on governance, a growing body of literature highlights the deficiencies of public governance of biofuels sustainability (Ekener-Petersen et al., 2014; Fargione et al., 2008; MacKay, 2009; Plank, 2016; Searchinger et al., 2008). In their review of literature on the political economy of biofuel policies in the US, Brazil and the EU, Oliveira et al (this issue) find that biofuel policies are not developed and implemented according to the desire to achieve environmentally sustainable or inclusive growth, but according to state interests in energy security and its intersection with private profit. Biofuel production advances furthest when relevant industry sectors align with each other and state interests in energy security take precedence over food security, and stalls when major corporate sectors are in tension, state concerns over food security predominate or opportunities for profit are limited. Accompanying these trends are the privatization of profit by corporations and the tendency to transfer the costs of industry establishment to the public. The processes involved were found to render policy mechanisms aiming to advance social and environmental sustainability ineffective, while upholding unsustainable and inefficient energy practices (Gillon, 2016; Oliveira and Schneider, 2016; Vogelpohl, 2014).

As de Man et al. (this issue) demonstrate, market-based governance through certification is a poor substitute for government regulation in advancing biofuel sustainability. This stems from a host of factors, from limited market share to the tendency for the certified market share to suffer from limited additionality and represent standards of questionable quality (Cashore et al., 2007; German and Schoneveld, 2012; Goovaerts et al., 2013; Ponte, 2014). Multistakeholder roundtables have produced some of the more robust standards, but their market share is often limited and their governance not immune to the influence of powerful actors in industry and government (de Man et al., this issue; Partzsch, 2011; Ponte, 2013; Ruysschaert and Salles, 2014; von Geibler 2013). A number of sustainability challenges are also ill-suited to a market-based approach, particularly those that go beyond risk mitigation to advancing social aims or those that require actions beyond the level of the production unit (e.g. cumulative impacts at landscape scale, wider governance shortcomings, or alignment of sector development trajectories with government policy aims) (Guariguata et al., 2011; Selfa et al., 2014; von Geibler, 2003). Consequently, certification too often serves to legitimize company practices while masking negative realities on the ground (Partzsch, 2011). Thus, while marketbased instruments may have a role to play in reducing the costs of norm generation and compliance/enforcement, the proliferation of low quality standards conferring green labels and their voluntary nature (and thus, low market share) undermine their potential. 
Final approved version of manuscript published in 2017 in Energy Policy. For final published manuscript, please see: http://dx.doi.org/10.1016/j.enpol.2017.04.013

Many herald the EU's Renewable Energy Directive as a novel attempt to hybridize state regulation with market-based certification. While it appears to align many standards with EUdefined environmental sustainability criteria, the substantive scope of sustainability criteria is restricted to environmental concerns. As a result, addressing social sustainability is voluntary, the quality of schemes used to verify compliance varies widely, and producers tend to opt for the weaker standards (German and Schoneveld, 2012).

\section{IMPLICATIONS FOR POLICY AND PRACTICE: SINE QUA NONS FOR SUSTAINABLE BIOFUELS}

In this concluding section, we draw on the evidence presented on the effectiveness and sustainability of national biofuel programs, the lessons derived from this evidence and the wider literature to ask, "What next?" for countries wishing to advance national biofuel programs. Deriving prescriptions for future action based on evidence of past performance and theories of change is fraught with uncertainty. The sine qua nons for sustainable biofuel governance presented below are therefore advanced not as silver bullets, but as elements which if advanced with intention and good faith, are likely to enhance the likelihood of more successful, sustainable biofuel programs across a range of indicators.

\subsection{Taking a Step Back: What to Consider before Deciding to Promote Biofuels}

While many countries jump into biofuels in response to international climate commitments or domestic agendas (e.g. energy security), the patchy performance of biofuels to date across a range of indicators compels a deeper evaluation before embarking on a national biofuel program. The papers in this collection demonstrate how myths about biofuels have outpaced concrete achievements and supporting evidence - from climate mitigation potential to prospects for livelihood improvement or our ability to effectively govern for sustainability. Furthermore, the unique footprints of different feedstocks, business models, actor constellations and contexts (land covers, land uses and livelihoods) and the complexities of change processes themselves mean that outcomes of any policy intervention are indeterminate. Given the complexity of these influences, and of the social and ecological systems in which they are embedded, the very best of policies and planning efforts will still fail to anticipate the course of events and their outcomes - including social responses. This points to the need for a knowledge-intensive, evidence-based and inclusive process. This section describes six steps that such a process should involve prior to any decision to promote or scale up biofuels.

\section{Articulate program aims and expectations.}

What is it that a national biofuel program hopes to achieve? What are the primary motivations that must be satisfied if the program is to be considered a success, and what co-benefits are hoped for? Finally, how will goal achievement be measured? Inherent trade-offs in biofuel programs require that policy goals and expectations be disentangled to independently plan and assess them (Hunsberger et al., this issue). Policy goals also need to be defined in less ambiguous and more ambitious terms, to align subsequent evaluations of progress towards them with realities playing out on the ground. 
Final approved version of manuscript published in 2017 in Energy Policy. For final published manuscript, please see: $\underline{\text { http://dx.doi.org/10.1016/j.enpol.2017.04.013 }}$

To robustly articulate aims and metrics that reflect the interests of society at large, this step should be inclusive and deeply deliberative. This means involving actors representing the interests of those likely to be affected by policy decisions (including organizations representing the interests of local land users). It also requires a well-designed process in which decisions are reached through deep deliberation over alternative choices and preferences (Dryzek, 2000; Elster, 1998). This process should involve several features: a discussion in which all participants are treated as free and equal citizens, which leads to the transformation rather than simple aggregation of preferences (Elster, 1998), and which involves persuasion rather than coercion, manipulation or deception (Dryzek, 2000). Given the strategic nature of discussions at this stage and the likelihood of unequal "deliberative competence" among actors, non-governmental organizations staffed with those knowledgeable about biofuels but accountable to community interests may need to be called on to represent local interests.

Since substituting current energy consumption levels with sustainable biofuels is impossible even if only applied in the transport sector, this process must also include deliberation about production and commercialization practices that affect overall energy demand (MacKay, 2009). Particularly in highly-industrialized countries and fast-growing economies, substantial efforts must be made to replace energy-intensive production and commercialization practices (such as industrial agriculture) with more sustainable alternatives that reduce overall consumption.

\section{Assess under what conditions, if any, biofuels can deliver on identified aims.}

This is an intensive analytical step which, depending on the aims articulated in step 1, likely requires expertise from multiple disciplines and sectors. In addition to asking whether biofuels can deliver on primary aims, it is important to explore the circumstances under which broadbased benefits may be achieved (e.g. rural livelihood and/or energy security gains maximized).

If climate change mitigation is identified as one of the primary motivations for national biofuel programs, it is fundamentally important to get the numbers right at this stage given the prevalence of accounting errors in producing overly idealistic projections (Chum et al., 2011; Creutzig et al., 2015; Searchinger, this issue). This means accounting for the opportunity costs of using land and biomass for biofuels. Only if the opportunity cost of land (or biomass or carbon) is very small and the benefit very high, should biofuel programmes be pursued as a strategy for climate mitigation. Given the restricted circumstances in which this tends to be true, if climate mitigation is a mandatory goal for the biofuel programme, the programme should generally focus on sources of waste material.

Another key component of this analysis should be explicitly identifying trade-offs likely to accompany different feedstock and biofuel production scenarios, so that a focus on primary motivations for a biofuel programme does not blind decision-makers to the costs of different courses of action. The papers in this issue identify a tendency for trade-offs rather than "winwins": trade-offs between policy aims; between food, fiber and fuel; between private and public interests; and between sector competitiveness and energy security on the one hand, and social and environmental sustainability on the other (Hunsberger et al., this issue; Oliveira et al., this issue; Searchinger and Beringer, this issue). To reflect growing demands for food, fiber and 
Final approved version of manuscript published in 2017 in Energy Policy. For final published manuscript, please see: http://dx.doi.org/10.1016/j.enpol.2017.04.013

urban development and the highly uneven effects of specific investment strategies, these scenarios should include alternative business models and possible land use-land cover change trajectories for the area in question. Given the prominent role of agronomics in shaping where biofuel feedstock may be grown and which business models are feasible, this analysis should be done for each potential feedstock. It should also draw on actual performance to date rather than assumptions embedded in models. Further, this analysis should investigate the livelihood benefits and costs of different models of ownership and control of production, processing and marketing. This research should explore the feasibility of decentralising ownership and control so as to maximise the social benefits of biofuel programmes.

\section{Assess global repercussions of national policy choices.}

It is crucial for countries to consider the global repercussions of biofuel programmes aimed at increasing the level of national consumption. Can the feedstock be provided locally, or regionally? If not, where is the biomass or biofuel to be imported from? What measures are in place to ensure that it has been produced sustainably? Can the scale of the state-initiated demand for biofuels (e.g., mandates) be satisfied in a socially and environmentally sustainable manner, considering projected demand from other countries? Does the global biofuels regime foster supply chains that moderate the traditional South-North divide, or does it follow a similar division of labour, impeding socio-economic change towards greater equality? If no reasonable answers or assurances can be provided for these critical questions, sustainability is likely to be jeopardised. Moreover, costs of bioenergy production are likely to be primarily borne by societies and ecosystems of tropical and non-industrial countries (Buchholz and Volk, 2012) undermining any advancement in global social and environmental justice.

\section{Identify the acceptability of the trade-offs associated with alternative production scenarios.}

While step 2 is an analytical step carried out by those with relevant scientific expertise and knowledge of the host country context, identifying the acceptability of trade-offs is a deliberative step focused on the negotiation of societal values. If biofuels that deliver climate benefits can only be produced at the expense of food production, for example, is it socially and politically acceptable to do so? If energy security aims can be best achieved through large-scale industrial production and processing, how will these aims be reconciled with social sustainability concerns?

\section{Evaluate whether biofuels are the best available means of achieving identified aims.}

Given the poor performance of biofuels in meeting many prominent rationales for biofuel programs, many have begun to pose the question, "Are there more suitable alternatives to meeting these same policy goals that carry fewer risks and trade-offs?" Answering this question requires a comparative analysis of the climate and ecological footprints of different energy options (e.g. biofuel vs. electricity or solar), and the likely social benefits/risks of different energy options for the country in question (see, for example, Searchinger and Beringer's discussion of solar in this issue). 
Final approved version of manuscript published in 2017 in Energy Policy. For final published manuscript, please see: $\underline{\text { http://dx.doi.org/10.1016/j.enpol.2017.04.013 }}$

\section{Decide whether to move forward with the proposed biofuel program.}

This step is where the decision to move ahead with the proposed biofuel program, halt the program, or take alternative action (e.g. alternative energy options) is made. Some of the questions that should be explored include: Do we need biofuel? Is it a solution to the climate problem? Is it the best strategy for meeting other aims? Do the expected trade-offs and risks merit moving forward with the current vision, or does it require adjustment? Is it necessary to re-consider the decision to promote biofuels? If alternative means are found to achieve the same goals, and these alternatives carry fewer trade-offs or risks, then these alternatives should be considered as a substitute for a national biofuel program.

If biofuels continue to out-perform other options for achieving established policy aims following the first set of steps articulated above, the additional sine qua nons articulated below would come into play in the course of planning and implementation.

\subsection{Adaptive Collaborative Management of Policy Planning and Implementation}

If a decision is made to initiate a national biofuel programme, an adaptive and collaborative approach is warranted. Being adaptive means the programme is not fixed from its implementation until its completion; rather it is a knowledge-intensive and iterative process in which monitoring and feedback from affected groups guide mid-course corrections based on actual performance (including both planned and unanticipated impacts). This helps address the uncertainty of interventions involving complex natural, social and political systems. Being collaborative means that plans are not formulated, implemented and monitored by centralised bureaucracies alone, but in an inclusive fashion - involving those affected at different stages in the process of planning, implementation, monitoring and evaluation.

\section{Carry out an evidence-based, participatory and deliberative planning process.}

The next sine qua non for sustainable biofuels is a planning process that is evidence-based and pluralistic. The evidence to support planning comes in multiple forms, depending on the stage of planning and implementation. At this stage, evidence from the analyses carried out in the analytical and deliberative steps articulated above serves as an input to planning processes involving directly affected stakeholders. At later stages, evidence will come from pilot projects that demonstrate how a plan plays out in reality as it confronts technical and financial challenges to implementation, interacts with different interest groups, and experiences climatic and ecological realities. In a process designed to consist of iterative cycles (of planning, implementation, monitoring, reflection and re-planning), evidence will also emerge from the experiences of those involved in the process: communities, the private sector, government and non-governmental agents of change.

Some points of deliberation in this multi-level planning process should include:

a) What forms of biomass/biofuel? The choices will be narrowed in prior steps which assess the ability of different feedstocks in different locations to achieve strategic policy objectives. Yet some latitude of choice is likely to remain. These choices and their 
Final approved version of manuscript published in 2017 in Energy Policy. For final published manuscript, please see: http://dx.doi.org/10.1016/j.enpol.2017.04.013

implications for the trajectory of the sector (e.g. the degree of likely decentralisation of production and processing, degree of mechanisation and its implications for employment intensity, degree of monopsony and its implications for smallholders) should be the subject of deep deliberation with affected communities.

b) What scale of biomass/biofuel demand can be satisfied sustainably? What is realistic? Here, the aforementioned deliberation on the social acceptability of trade-offs is key. Methodologies to identify geographies of severity and the social acceptability of identified trade-offs are urgently needed.

c) What business models? Awareness must be created on the available options and their implications for business ownership, control over land and control over production (see Cotula and Leonard, 2010; German et al., 2016). The most prevalent options for most feedstock include: large-scale industrial operations where a company owns the business and controls land and production; independent smallholders producing for market, in which smallholders own the business and control land and production; and production contracts, in which a company owns the business, smallholders retain land ownership and both parties have rights and stakes over production (via a contract specifying the quantity and quality of feedstock to be supplied). Key criteria in selecting business models and designing agreements should be that they meet the needs of local stakeholders (communities, farmers) and mitigate risks to them (e.g. loss of land and livelihoods, indebtedness). Extra scrutiny should be applied when industrial-scale business models are considered - given the long-term risks they pose to fundamental rights and local livelihoods in most situations (Cotula and Leonard, 2010).

d) What kind of land use change? Biofuel feedstock production can induce many types of land use and land cover change, each affecting the sustainability of biofuels and local livelihoods. Feedstock choice often has a defining role in shaping the landscapes targeted for biofuels, given their agronomic requirements. Within targeted landscapes, governance instruments should have a defining role in shaping what land cover changes are permitted (for achieving strategic objectives and mitigating harm), while business models will have a defining role in shaping what land uses must be given up to accommodate biofuels. In Mozambique, methodological innovations have been tested to lead smallholders through a process of articulating where different business models might fit within existing land uses, maximizing the compatibility of incoming investments with existing livelihood activities (ORAM-Nampula and German 2014).

e) What type of smallholders? Central governments, prioritizing productivity of market crops over other land use values, often have a very different vision for smallholder agriculture than smallholders themselves. The vast literature documenting negative effects of biofuels on smallholders suggests a need to emphasize the following within biofuel programs:

- Diverse family farms rather than monoculture production, as a means to safeguard food security and buffer risks of market engagement; 
Final approved version of manuscript published in 2017 in Energy Policy. For final published manuscript, please see: $\underline{\text { http://dx.doi.org/10.1016/j.enpol.2017.04.013 }}$

- Flex crops with alternative household uses and markets over single purpose biofuel crops, so as to minimize the risks associated with single buyers and buffer uncertain demand and market prices for biofuels;

- Feedstocks that are compatible with the existing farming system in terms of peak labor demand and other features, so as to minimize labor competition with activities promoting food security.

2. Level the playing field for more effective participation of less powerful actors.

Reconciling the interests of nation states with the interests and values of other actors (most notably, local land users) requires additional activities to complement those articulated above. The aim should be to establish whether the interests of key players crucial to realising the vision (e.g., government, local communities, private sector) are compatible, and if not, to what extent they can be reconciled. There are many possible ways to approach this. From a purely social standpoint, a bottom-up approach might be prioritised in which local livelihood aspirations are identified, and ways for biofuel production to best advance these aspirations explored. Yet this approach may not ensure climate mitigation or other strategic interests are achieved. A second approach would be to start with the production scenarios identified as being feasible in meeting the objectives identified by diverse stakeholders, and explore their articulation with existing land uses and community aspirations. The second strategy will only help reconcile national and local interests if there is ample opportunity for affected land users to understand, contest or shape the options under consideration.

Efforts are likely also needed to level the playing field of "deliberative competence", "epistemic pluralism" and "voice" to enable all those directly affected by biofuel projects and programmes to play a meaningful role in shaping decisions. Enhancing deliberative competence means taking the time to ensure alternative courses of action and their stakes (e.g., for land use, land tenure, livelihoods) are understood, while ensuring affected households and individuals can advocate for choices they view as more beneficial and carrying fewer costs. Epistemic pluralism requires creating a respectful environment in which different values and ways of knowing and being in the world can be articulated and welcomed on their own terms, without having to reach consensus or erase difference (Dryzek, 2000; Hirsch et al., 2011). Finally, it means managing very unequal power dynamics, notably between the government and private sector on one hand and local communities on the other - but also within local communities as outside actors seek to stoke divisions or buy favor. This means facilitating a planning process absent of coercion, manipulation or deception, but also one in which persuasion only enters the process if all participants are able to wield it effectively (Dryzek, 2000).

While many tools exist to support such processes (FAO, 2012; McDougall et al., 2009; Prabhu et al., 1999; Wollenberg et al., 2000), community development practitioner-advocates and critically-minded social scientists know all too well how hard these ideas are to put into practice in relation to programmes initiated by centralised bureaucracies in the modern nation-state. To ensure meaningful participation, separate fora specifically for smallholder producers and communities affected by biofuel expansion are likely needed to enable less powerful or 
Final approved version of manuscript published in 2017 in Energy Policy. For final published manuscript, please see: $\underline{\text { http://dx.doi.org/10.1016/j.enpol.2017.04.013 }}$

outspoken actors to articulate their concerns. This will help give them a voice independent from the influence of politically and economically powerful actors, while providing checks and balances on programme-level decision-making. A formal mechanism for feeding the results of these deliberations into multi-stakeholder planning fora will be needed for this strategy to effectively shape programme-level dialogue and decisions. Engaging community advocates knowledgeable about the risks and constraints faced by local communities in the planning process can help bring local concerns and interests into multi-stakeholder planning fora. Professional moderation of such processes is central.

3. Ensure the wider governance context supports policy aims established in the biofuel sector, particularly those related to social inclusion and social and environmental risks.

Outcomes of biofuel policies depend significantly on the wider governance context, including foreign investment, land tenure, environmental protection, labour standards, and agriculture and rural development. If regulations and/or enforcement in these other areas are weak, biofuel programmes will likely fail no matter how adaptively and collaboratively they are planned. On the other hand, the processes highlighted under sine qua non \#2 might also be leveraged to strengthen the broader policy environment.

\section{Carry out evidence-based reforms of governance instruments.}

The papers in this collection show clearly that biofuel production will not be sustainable, responsible or pro-poor through the spontaneous actions of actors operating independently without accountability to other actors or policy aims. The papers by Searchinger and Beringer, Hunsberger et al. and Goetz et al. (this issue) highlight the divergence between official policy aims and actual outcomes, while the papers by Hunsberger et al. and Oliveira et al. (this issue) highlight the tendency for the sector to evolve towards more capitalized and intensive operations favoring benefit capture by large corporations. Sector governance is urgently needed to ensure environmental sustainability and benefits for the rural poor. Yet clearly current instruments are falling short of this objective.

In the absence of better accounting methods and governance instruments that hold producers accountable to the collective goods (environmental and social) enshrined in public policy, biofuel programmes will continue to fail in delivering social and environmental sustainability. Moving forward in the absence of concerted efforts to improve public governance of the sector invites continued failure to achieve the expectations accompanying biofuel programmes. Stronger public governance is clearly needed in producer countries. In Indonesia, for example, early government efforts to mandate a minimum percentage of production from smallholders and to work with industry to ensure quality services for small-scale producers led to significant levels of smallholder participation in oil palm. While aligning public policies with market-based instruments may help overcome some of the constraints of public governance (e.g. reducing enforcement costs, reconciling sustainability criteria with the profit imperative), there is no viable substitute for the state guiding the trajectory of the sector - particularly if pro-poor sector development is a concern. 
Final approved version of manuscript published in 2017 in Energy Policy. For final published manuscript, please see: $\underline{\text { http://dx.doi.org/10.1016/j.enpol.2017.04.013 }}$

\section{Foster innovation in efforts to benefit the poor.}

Creativity is also needed in exploring how to ensure gains to smallholders - especially those who are most disadvantaged. Smallholders who participate in the biofuel sector do not automatically benefit. Indeed, efforts to increase smallholder biofuel production have produced very uneven outcomes, with opportunities and benefits largely bypassing the poorest farmers, those in the most remote areas and those who lack secure land rights (Hunsberger et al., this issue). Beyond mandating minimum production levels from smallholders, what initiatives might advance pro-poor outcomes in the industry - whether by increasing benefits captured at the local level or mitigating risk? What benefits might be achieved by limiting industrial-scale operations to processing rather than feedstock production, while supporting smallholder incorporation into the value chain? By emphasising only flex crops? By setting aside areas near any biofuel project to safeguard traditional livelihoods and nutrition? By increasing public finance to the independent smallholder sector?

\section{Foster learning and iterative improvement throughout policy implementation.}

Even the best-laid plans will encounter challenges, surprises and undesirable effects. To minimise the effect of these unintended consequences, two crucial ingredients are needed: pilot evaluation of programmes before scaling up, and making feedback and learning a central component of scaling up.

\subsection{Proof of Concept: Pilot Evaluation}

Given what we know about uncertainties, it is important to evaluate biofuel programs on a small scale before trying to take programs to scale. Where established biofuel programs or pilot projects exist, every effort should be made to learn from them what to replicate, adjust or simply avoid. Where biofuel programs are new, or where innovations in established programs are envisioned, pilot projects need to be designed, implemented and evaluated before plans are rolled out. These pilots should include each of the feedstocks, business models and land use change scenarios envisioned in the planning process, and be designed to increase the likelihood of environmentally sustainable and pro-poor outcomes.

A robust evaluation of the sustainability of these pilot innovations is needed before deciding which feedstock and biofuel production strategies to pursue (and related land use-land cover changes to welcome) at scale. Evaluations should focus on: the degree to which program aims have been met at the local scale; the benefits and risks to directly affected households (smallholders, employees, anyone losing land to an incoming investment); and any trade-offs that have become apparent. This process should be duly deliberative and include diverse perspectives and knowledge forms, including scientific evidence, specified policy aims, and local experiences with biofuels.

\subsection{Scaling Up}

Should pilot experiences meet expectations in terms of the chosen goals and indicators, scaling up the proven feedstock and production scenarios can be considered. As the science of scaling 
Final approved version of manuscript published in 2017 in Energy Policy. For final published manuscript, please see: http://dx.doi.org/10.1016/j.enpol.2017.04.013

suggests that fundamental changes in the nature of the production system can be expected when taking a successful innovation to scale, it cannot be assumed that the outcomes obtained within pilots will be replicated at scale. Risks and pitfalls are likely to be many and multifaceted. This points to two crucial steps of analysis and interrogation. First, it is important to critically consider existing scenarios and future plans. At every stage, the question of whether scaling up is the appropriate policy choice should be re-assessed in the face of new data, policy alternatives, opportunity costs, and the sustainability goals that upscaling is expected to deliver. Second, should the decision to scale up remain uncontested after this critical reflection, applying lessons from efforts to upscale elsewhere becomes central to planning and change management. Uncertainties should be assumed, and feedback and learning made central to policy formulation and implementation (Gunderson, 1999). A formal monitoring programme is needed to track the performance of indicators linked to policy aims, alongside deliberative spaces designed to capture feedback from stakeholders directly affected by biofuel programmes. The latter will help retain a focus on pluralism and inclusivity by extending deliberation from planning through to monitoring, as well as capturing unanticipated effects before they lead to programme failure. When problems are identified, whether through divergence between programme aims and performance or from stakeholder feedback, further deliberation is needed to explore how to adjust plans and mitigate negative impacts while building on successes valued locally. An exit strategy should also be contemplated, given the possibility that particular production scenarios are less promising than initially assumed, or that establishing new forms of production might lock in a new status quo and thereby lock out alternatives. Where experiences meet local expectations but fail to achieve one or more strategic policy goals, the providing ongoing support to the programme should be considered. Where the opposite is true and local livelihoods are clearly at risk in the process of meeting strategic priorities, changing the course of action should be considered a must.

\section{CONCLUSIONS}

Biofuels have been promoted worldwide under the assumption that they can support several strategic yet unresolved policy goals, such as transitioning towards a more secure and climatefriendly energy system, while delivering co-benefits to workers and rural communities and mitigating harm. Drawing on the best published evidence to date, contributing papers to this special issue question these assumptions. By distilling the lessons from these companion reviews and consulting the wider literature on scaling and change management, this paper has formulated a series of sine qua nons for national biofuel programmes with the aim of enhancing their social and environmental sustainability. We conclude that these "indispensables" are the minimum conditions for achieving more equitable and sustainable biofuels, and national biofuel programmes should not be pursued in their absence. The 'success' of any biofuel programme that hopes to deliver on multiple aims will ultimately require an adaptive, collaborative and knowledge-intensive approach that treats policy innovation as experimentation, addresses power imbalances, and uses inclusive processes to set targets, monitor performance and change course in the face of evidence of environmental and social harms. While these indispensables may seem overly idealistic in light of current policy processes, we find value in identifying aspirational principles according to which the complexities, trade-offs and risks of 
Final approved version of manuscript published in 2017 in Energy Policy. For final published manuscript, please see: $\underline{\text { http://dx.doi.org/10.1016/j.enpol.2017.04.013 }}$

new technologies should be engaged. With large amount of public finance supporting the evolution of successful national biofuel programs (Mabee 2007; Peters and Thielman 2008), the limitations in aligning practice with these principles are less financial than ideological, cultural and political (Eaton et al. 2014; Oliveira et al., this issue).

Findings also highlight crucial conversations that lie outside the scope of biofuels sustainability. Current levels of global energy consumption, even only in the transport sector, cannot be met by biomass-derived agrofuels in a way that meets social aims and environmental goals. Perhaps the most fundamental sine qua non is therefore to pursue options that downscale global energy demand.

\section{Acknowledgements}

The authors would like to acknowledge the contributions of all of those present at the workshop, "Bioenergy: Status Quo, Trends and Sustainability Governance" hosted by the Institute for Advanced Sustainability Studies (IASS-Potsdam) in Berlin in October, 2015, where the notion of sine qua nons for sustainability governance was first discussed. In addition to the authors of this working paper, they include: Maria Backhouse, Reinier de Man, Tim Beringer, Oscar Schmidt, Ira Matuscke, Melf Ehlers, Karl Zimmerer, Jan Seven, Helen Watson, Ivonne Alva Lobos, and Felix Ekardt.

\section{References Cited}

Achten, W. M. J., and L. V. Verchot. 2011. Implications of biodiesel-induced land-use changes for $\mathrm{CO} 2$ emissions: Case studies in tropical America, Africa, and Southeast Asia. Ecology and Society 16(4): 14. http://dx.doi.org/10.5751/ES-04403-160414.

Ariza-Montobbio, P., Lele, S., 2010. Jatropha plantations for biodiesel in Tamil Nadu, India: Viability, livelihood trade-offs, and latent conflict. Ecological Economics 70, 189-195.

Armitage, D.R., Plummer, R., Berkes, F., Arthur, R.I., Charles, A.T., Davidson-Hunt, I.J., Diduck, A.P., Doubleday, N.C., Johnson, D.S., Marschke, M., McConney, P., Pinkerton, E.W., Wollenberg, E.K., 2008. Adaptive co-management for social-ecological complexity. Frontiers in Ecolology and Environment 6. doi:10.1890/070089

Barlow, C., Zen, Z., Gondowarsito, R., 2003. The Indonesian oil palm industry. Oil Palm, Industry Economic Journal 3, 8-15.

Bergius, M., 2012. Large-scale agro investments for biofuel production in Tanzania: Impact on rural households. Institute of Development Studies, University of Agder.

Bickel, U., Dros, J.M., 2003. The impacts of soybean cultivation on Brazilian ecosystems: Three case studies. World Wildlife Fund Forest Conversion Initiative.

Binswanger, H., 1986. Agricultural mechanization: A comparative historical perspective. The World Bank Research Observer 1, 27-56. 
Final approved version of manuscript published in 2017 in Energy Policy. For final published manuscript, please see: http://dx.doi.org/10.1016/j.enpol.2017.04.013

Borras, S., McMichael, P., Scoones, I., 2010. The politics of biofuels, land and agrarian change: Editors' introduction. The Journal of Peasant Studies, 37(4), 575-592

Brechin, S., Wilshusen, P., Fortwangler, C., West, P., 2003. Contested Nature: Promoting International Biodiversity with Social Justice in the Twenty-first Century. State University Press of New York, Albany.

Brosius, J.P., Russell, D., 2003. Conservation from above: An anthropological perspective on transboundary protected areas and ecoregional planning, in: U.M. Goodale, M.J. Stern, C. Margoluis, A. G. Lanfer, M. Fladeland (eds.), Transboundary Protected Areas: The Viability of Regional Conservation Strategies. Food Products Press, Binghampton, pp. 39-66.

Buchholz, T., Volk, T. A., 2012. Considerations of project scale and sustainability of modern bioenergy systems in Uganda. Journal of Sustainable Forestry 31 (1-2), 154-173.

Caroko, W., Komarudin, H., Obidzinski, K., Gunarso, P., 2011. Policy and institutional frameworks for the development of palm oil-based biodiesel in Indonesia. Center for International Forestry Research, Bogor, Indonesia.

Cashore, B., Auld, G., Bernstein, S., McDermot, C. 2007. Can non-state governance 'ratchet up' global environmental standards? Lessons from the forest sector. Review of European, Comparative and International Environmental Law 16 (2), 158-172. doi: 10.1111/j.14679388.2007.00560.x

Cheng, J. J., Timilsina, G. R., 2011. Status and barriers of advanced biofuel technologies: A review. Renewable Energy 36 (12), 3541-3549.

Chum, H., Faaij, A., Moreira, J., Berndes, G., Dhamija, P., Dong, H., Gabrielle, B., Eng, A.G., Lucht, W., Mapako, M., Cerutti, O.M., Mclntyre, T., Minowa, T., Pingoud, K., 2011. Bioenergy, in: Edenhofer, O., Pichs-Madruga, R., Sokona, Y., Seyboth, K., Matschoss, P., Kadner, S., Zwickel, T., Eickemeier, P., Hansen, G., Schlömer, S., von Stechow, C. (Eds.), IPCC Special Report on Renewable Energy Sources and Climate Change Mitigation. Cambridge University Press, Cambridge, United Kingdom and New York, NY, USA.

Colchester, M., 2011. Palm oil and indigenous peoples in South East Asia: land acquisition, human rights violations and indigenous peoples on the palm oil frontier. Forest Peoples Programme and the International Land Coalition, Moreton-in-Marsh, UK and Rome, Italy.

Colchester, M., Chao, S., 2011. Oil palm expansion in South East Asia: trends and implications for local communities and indigenous peoples. Forest Peoples Programme and Sawit Watch, Moreton-in-Marsh, UK and Bogor, Indonesia.

Colfer, C.J.P., 2005. The Complex Forest: Communities, Uncertainty and Adaptive Collaborative Management. Resources for the Future, Washington, D.C.

Cotula, L., Leonard, R., 2010. Alternatives to land acquisitions: Agricultural investment and collaborative business models. IIED, London. 
Final approved version of manuscript published in 2017 in Energy Policy. For final published manuscript, please see: http://dx.doi.org/10.1016/j.enpol.2017.04.013

Creutzig, F., Ravindranath, N.H., Berndes, G., Bolwig, S., Bright, R., Cherubini, F., Chum, H., Corbera, E., Delucchi, M., Faaij, A., others, 2015. Bioenergy and climate change mitigation: an assessment. GCB Bioenergy 7, 916-944. doi:10.1111/gcbb.12205

Dale, V. H., Lowrance, R., Mulholland, P., Robertson, G. P., 2010. Bioenergy sustainability at the regional scale. Ecology and Society 15(4), 23. [online] URL:

http://www.ecologyandsociety.org/vol15/iss4/art23/

de Andrade, R.M.T., Miccolis, A., 2011. Policies and institutional and legal frameworks in the expansion of Brazilian biofuels. Working Paper 71. Center for International Forestry Research, Bogor.

Deininger, K., Byerlee, D., Lindsay, J., Norton, A., Selod, H., Stickler, M., 2011. Rising global interest in farmland: Can it yield sustainable and equitable benefits? Washington D.C., The World Bank.

Dryzek, J.S., 2000. Deliberative Democracy and Beyond: Liberals, Critics, Contestations. Oxford University Press, Oxford.

Dufey, A., 2008. Impacts of sugarcane bioethanol towards the Millennium Development Goals, in: Zuurbier, P., Vooren, J.v.d. (Eds.), Sugarcane ethanol: contributions to climate change mitigation and the environment. Wageningen Academic Publishers, Wageningen, The Netherlands, pp. 199-225Ekins, P., 1993. "Limits to growth" and "sustainable development": Grappling with ecological realities. Ecological Economics 8, 269-288.

Eaton, W.M., Gasteyer, S.P., Busch, L., 2014. Bioenergy futures: Framing sociotechnical imaginaries in local places. Rural Sociology 79(2), 227-256.

Ekener-Petersen, E., Hoeglund, J., Finnveden, G., 2014. Screening potential social impacts of fossil fuels and biofuels for vehicles. Energy Policy 73, 416-426.

Elster, J., 1998. Deliberative Democracy. Cambridge University Press, Cambridge.

Erb, K. H., Lauk, C., Kastner, T., Mayer, A., Theurl, M. C., Haberl, H., 2016. Exploring the biophysical option space for feeding the world without deforestation. Nature communications, 7.

EU, 2009. Directive 2009/28/EC of the European Parliament and of the Council on the promotion of the use of energy from renewable sources, L 140/16. Official Journal of the European Union, Brussels.

FAO, 2012. Voluntary Guidelines on the Responsible Governance of Tenure of Land, Fisheries and Forests in the Context of National Food Security. Food and Agriculture Organization of the United Nations, Rome.

Feintrenie, L., Chong, W.K., Levang, P., 2010. Why do Farmers Prefer Oil Palm? Lessons Learnt from Bungo District, Indonesia. Small-scale Forestry 9, 379-396. 
Final approved version of manuscript published in 2017 in Energy Policy. For final published manuscript, please see: http://dx.doi.org/10.1016/j.enpol.2017.04.013

Franco, J., Levidow, L., Fig, D., Goldfarb, L., Hönicke, M., Mendonça, L.M., 2010. Assumptions in the European Union biofuels policy: Frictions with experiences in Germany, Brazil and Mozambique. The Journal of Peasant Studies 37 (4), 661-698.

Gasparatos, A., Stromberg, P., 2012. Socioeconomic and environmental impacts of biofuels: Evidence from developing nations. Cambridge University Press, Cambridge.

Gallagher, E., ed. 2008. The Gallagher Review of the Indirect Effects of Biofuels Production. Renewable Fuels Agency, London.

Gerber, N., van Eckert, M., Breuer, T., 2008. The impacts of biofuel production on food prices: a review. ZEF - Discussion Papers on Development Policy No. 127. Center for Development Research, Bonn.

German, L.A., 2015. The global land rush: implications for agricultural communities. CAB Reviews 10 (33), 1-19.

German, L., 2014. Multi-sited governance of large-scale land acquisitions: Mapping the terrain. Review of Policy Research 31 (3), 218-252.).

German, L., Cavane, E., Sitoe, A., Braga, C., 2016. Private investment as an engine of rural development: A confrontation of theory and practice for the case of Mozambique. Land Use Policy 51 (2016), 1-14.

German, L.A., Mowo, J.G., Amede, T., Masuki, K., 2011a. Integrated Natural Resource Management in the Highlands of Eastern Africa: From Concept to Practice. Earthscan, London.

German, L.A., Parker, L., 2015. Model development? Zambia Sugar and the uneven terrain of social benefit. Presented at the World Bank Conference on Land and Poverty. The World Bank, Washington, D.C.

German, L., Schoneveld, G., 2012. A review of social sustainability considerations among EUapproved voluntary schemes for biofuels, with implications for rural livelihoods. Energy Policy 51 (2012), 765-778.

German, L., Schoneveld, G.C., Pacheco, P., 2011b. The Social and Environmental Impacts of Biofuel Feedstock Cultivation: Evidence from Multi-Site Research in the Forest Frontier. Ecology and Society 16.

German, L.A., Unks, R., King, E., 2016. Green appropriations through shifting contours of authority and property on a pastoralist commons. The Journal of Peasant Studies, DOI: 10.1080/03066150.2016.1176562.

Gillon, S., 2016. Flexible for whom? Flex crops, crises, fixes and the politics of exchanging use values in US corn production. Journal of Peasant Studies 43, 117-139. Goetz, A., 2015. Pushing the Limits: International Land Acquisitions in Comparative Perspective. Theses and Dissertations (Comprehensive). Paper 1716. 
Final approved version of manuscript published in 2017 in Energy Policy. For final published manuscript, please see: http://dx.doi.org/10.1016/j.enpol.2017.04.013

Godar, J., Suavet, C., Gardner, T. A., Dawkins, E., Meyfroidt, P., 2016. Balancing detail and scale in assessing transparency to improve the governance of agricultural commodity supply chains. Environmental Research Letters 11 (3), 035015.

Goovaerts, L., et al., 2013. Strategic Inter-Task Study: Monitoring Sustainability Certification of Bioenergy - Task 1: Examining Sustainability Certification of Bioenergy. IEA Bioenergy. Gunderson, L., 1999. Resilience, flexibility and adaptive management: Antidotes for spurious certitude? Conservation Ecology 3 (1), 7. [online] URL: http://www.consecol.org/vol3/iss1/art7/

Hartemink, A.E., 2008: Chapter 3, Sugarcane for bioethanol: Soil and environmental issues. In: D.L. Sparks (Ed.), Advances in Agronomy 99, 125-182. Elsevier, London.

Hawkins, D., Chen, Y., 2011. Plant with a bad name. Hardman \& Co, London.

Herrmann, R., Grote, U., 2015. Large-scale agro-industrial investments and rural poverty: Evidence from sugarcane in Malawi. Journal of African Economies 24, 645-676.

Hickey, J., 2010. 'No hot air' about renewable energy while blowing smoke: David Mackay plays 'Brutus' to the sun's 'Caesar'. Justmeans.com (August 18, 2010).

Hirsch, P.D., Adams, W.M., Brosius, J.P., Zia, A., Bariola, N., Dammert, J.L., 2011. Acknowledging conservation trade-offs and embracing complexity. Conservation Biology Apr 25 (2), 259-64. doi: 10.1111/j.1523-1739.2010.01608.x.

Jasanoff, S., Kim, S.-H., 2009. Containing the atom: Sociotechnical imaginaries and nuclear power in the United States and South Korea. Minerva 47, 119-146.

Jefferson, M., 2013. Challenges to global energy policy and supply security, in: Filho, W.L. and Voudouris, V. (Eds.), Global Energy Policy and Security. Springer, London, pp. 27-44.

Keeney, R.L, Raiffa, H., 1993. Decisions with Multiple Objectives: Preferences and Value Tradeoffs. Cambridge University Press, Cambridge.

Koh, L. P., Wilcove, D.S., 2008. Is oil palm agriculture really destroying tropical biodiversity? Conservation Letters 1 (2),60-64. http://dx.doi.org/10.1111/j.1755-263X.2008.00011.x

Lapola, D. M., R. Schaldacha, J. Alcamoa, A. Bondeaud, J. Kocha, C. Koelkinga, J. A. Priess, 2010. Indirect land-use changes can overcome carbon savings from biofuels in Brazil. Proceedings of the National Academy of Sciences 107 (8), 3388-3393. doi:10.1073/pnas.0907318107

Lee, K.N., 1999. Appraising adaptive management. Conservation Ecology 3 (2), 3. [online] URL: http://www.consecol.org/vol3/iss2/art3

León-Moreta, M., 2011. Biofuels: A threat to the environment and human rights-an analysis of the impact of the production of feedstock for agrofuels on the rights to water, land and food. European Journal of Legal Studies 4, 122.

Li, T.M., 2011. Centering labor in the land grab debate. Journal of Peasant Studies 38, 281-298. 
Final approved version of manuscript published in 2017 in Energy Policy. For final published manuscript, please see: http://dx.doi.org/10.1016/j.enpol.2017.04.013

Mabee, W.E., 2007. Policy options to support biofuel production. Advances in Biochemical Engineering/Biotechnology 108, 329-357.

Macedo, I.D.C., 2005. Sugarcane's Energy: Twelve Studies on Brazilian Sugarcane Agribusiness and its Sustainability. União da Agroindústria Canavieira de São Paulo, São Paulo, Brazil.

MacKay, D., 2009. Sustainable Energy - Without the Hot Air. UIT Cambridge.

McCarthy, J.F., 2010. Processes of inclusion and adverse incorporation: Oil palm and agrarian change in Sumatra, Indonesia. Journal of Peasant Studies 37, 821-850.

McDougall, C., Pandit, B.H., Banjade, M.R., Paudel, K.P., Ojha, H., Maharjan, M., Rana, S., Bhattarai, T., Dangol, S., 2009. Facilitating Forests of Learning: Enabling an Adaptive Collaborative Approach in Community Forest User Groups. Bogor, Indonesia: Center for International Forestry Research.

McKersie, B., Hichaambwa, M. 2011. Feasibility Study for the Enhancement and Extension of Kaleya Smallholder Scheme, Final Report. Thame, UK: Cardno Emerging Markets Ltd.

Miller, C., Erickson, P. 2006. The politics of bridging scales and epistemologies science and democracy in global environmental governance, in: Reid, W., Wilbanks, T., Capistrano, D., Berkes, F. (Eds.), Bridging Scales and Knowledge Systems: Concepts and Applications in Ecosystem Assessment. Island Press, Washington, D.C., pp. 297-314.

Mitchell, D. 2010. Biofuels in Africa: Opportunities, prospects, and challenges. The World Bank, Washington, D.C. Retrieved from http://elibrary.worldbank.org/doi/abs/10.1596/978-0-82138516-6.

MME, 2007. Política General en Materia de Biocombustibles. Ministerio de Minas e Energia, Brasilia.

MNRE, 2009. National Policy on Biofuels. Ministry of New and Renewable Energy, Government of India, New Delhi.

Mohr, A., Raman, S., 2013. Lessons from first generation biofuels and implications for the sustainability appraisal of second generation biofuels. Energy Policy 63, 114-122.

Montefrio, M.J.F., Sonnenfeld, D.A., 2013. Global-Local Tensions in Contract Farming of Biofuel Crops Involving Indigenous Communities in the Philippines. Society and Natural Resources 26, 239-253.

NABU and Transport and Environment, 2016. Cars and trucks burn almost half of palm oil used in Europe. Briefing, May 2016. Berlin and Brussels. https://www.nabu.de/imperia/md/content/nabude/verkehr/160530-nabu-studie-palmoelkraftstoff.pdf (accessed 30.11.2016). 
Final approved version of manuscript published in 2017 in Energy Policy. For final published manuscript, please see: http://dx.doi.org/10.1016/j.enpol.2017.04.013

NRDC, 2015. In the U.S. Southeast, natural forests are being felled to send fuel overseas. National Resources Defense Council, New York. https://www.nrdc.org/sites/default/files/southeast-biomass-exports-report.pdf (accessed 30.11.16).

Obidzinski, K., Andriani, R., Komarudin, H., Andrianto, A., 2012. Environmental and social impacts of oil palm plantations and their implications for biofuel production in Indonesia. Ecology and Society 17.

Oliveira, G. de L.T., Schneider, M., 2016. The politics of flexing soybeans: China, Brazil and global agroindustrial restructuring. Journal of Peasant Studies 43(1), 167-194.

ORAM-Nampula, German, L., 2014. Metodologia para o Zoneamento Participativo e a Avaliação da Compatibilidade do Investimento Privado com os Usos Actuais da Terra e as Aspirações Locais. Land Notes 1.

Ortiz, L., Rodrigues, D., 2006. Case study sugar cane ethanol from Brazil. CREM, Núcleo Amigos da Terra (NAT), Vitea Civilis Institute, São Lourenço da Serra, Brazil.

Ostrom, E., 2007. A diagnostic approach for going beyond panaceas. Proceedings of the National Academy of Sciences 104, 15181-15187.

Parson, E.A., Clark, W.C., 1995. Sustainable development as social learning: Theoretical perspectives and practical challenges for the design of a research program, in Gunderson, L.H., Holling, C.S., Light, S.S. (Eds.), Barriers and Bridges to the Renewal of Ecosystems and Institutions. Columbia University Press, New York, pp. 428-460.

Partzsch, L., 2011. The legitimacy of biofuel certification. Agriculture and Human Values 28, 413-425.

Peters, J., Thielman, S., 2008. Promoting biofuels: Implications for developing countries. Energy Policy 36(4), 1538-1544.

Pinkerton, E., 2007. Integrating holism and segmentalism: Overcoming barriers to adaptive comanagement between management agencies and multi-sector bodies, in: Armitage, D., Berkes, F., Doubleday, N. (Eds), Adaptive Co-management: Collaboration, Learning and Multi-level Governance. Vancouver, Canada: UBC Press.

Plank, C., in press. The agrofuels project in Ukraine: How oligarchs and the EU foster agrarian injustice, in: Pichler, M., Staritz, C., Küblböck, K., Plank, C., Raza, W., Ruiz Peyré, F., (Eds.), Fairness and Justice in Natural Resource Politics. Routledge.

Pleven, R. J., M. O'Hare, A. D. Jones, M. S., H. K. Gibbs, 2010. Greenhouse gas emissions from biofuels' indirect land use change are uncertain but may be much greater than previously estimated. Environmental Science and Technology 44:8015-8021.

http://dx.doi.org/10.1021/es101946t 
Final approved version of manuscript published in 2017 in Energy Policy. For final published manuscript, please see: http://dx.doi.org/10.1016/j.enpol.2017.04.013

Ponte, S., 2014. "Roundtabling" sustainability: Lessons from the biofuel industry. Geoforum 54, 261-271. doi:10.1016/j.geoforum.2013.07.008

Prabhu, R., Colfer, C.J. P., Dudley, R.G., 1999. Guidelines for Developing, Testing and Selecting Criteria and Indicators for Sustainable Forest Management: A C\&I Developer's Reference. The Criteria \& Indicators Toolbox Series. Center for International Forestry Research, Bogor, Indonesia.

Redford, K., Adams, W., 2009. Payment for ecosystem services and the challenge of saving nature. Conservation Biology 23, 785-787.

Republic of South Africa, 2007. Biofuels Industrial Strategy of the Republic of South Africa. Department of Minerals and Energy.

Roe, D., Walpole, M.J., 2010. Whose value counts? Trade-offs between biodiversity conservation and poverty reduction, in: Leader-Williams, N., Adams, W.M., Smith, R.J. (Eds.), Trade-offs in Conservation: Deciding What to Save. Oxford: Wiley-Blackwell.

Roos, G., 2010. Biofuel power stations take the heat for burning palm oil for electricity. Environmentalleader.com (April 13, 2010). http://www.environmentalleader.com/2010/04/13/biofuel-power-stations-take-heat-forburning-palm-oil-for-electricity/ (accessed 15.11.2016).

Ruysschaert, D., Salles, D., 2014. Towards global voluntary standards: Questioning the effectiveness in attaining conservation goals, the case of the Roundtable on Sustainable Palm Oil (RSPO). Ecological Economics 107 (2014), 438-446.

Schoneveld, G., German, L., Andrade, R., Chin, M., Caroko, W., Romero-Hernández, O., 2010. The role of national governance systems in biofuel development: A comparative analysis of lessons learned. CIFOR InfoBrief 35.

Schoneveld, G.C., German, L.A., Nutakor, E., 2011. Land-based investments for rural development? A grounded analysis of the local impacts of biofuel feedstock plantations in Ghana. Ecology and Society 16.

Schnoor, J.L., 2006. Biofuels and the environment. Environmental Science and Technology 40(13), 4042-4042. DOI: 10.1021/es0627141.

Searchinger, T.D., 2010. Biofuels and the need for additional carbon. Environ. Res. Lett. 5 (2010), 024007. doi:10.1088/1748-9326/5/2/024007

Seachinger, T.D., Hamburg, S.P., Melillo, J., Chameides, W., Havlik, P., Kammen, D.M., Likens, G.E., Lubowski, R.N., Obersteiner, M., Robertson, G.P., Schlesinger, W.H., Tilman, G.D., 2009. Fixing a critical climate accounting error. Science 326 (2009), 527-528. 
Final approved version of manuscript published in 2017 in Energy Policy. For final published manuscript, please see: $\underline{\text { http://dx.doi.org/10.1016/j.enpol.2017.04.013 }}$

Searchinger, T., Heimlich, R., Houghton, R.A., Dong, F.,Elobeid, A., Fabiosa, J.,Tokgoz, S., Hayes,D.,Yu, T.H., 2008. Use of U.S. croplands for biofules increases greenhouse gases through emissions from land-use change. Science 319(5867), 1238-1240.

Selfa, T., Bain, C., Moreno, R., 2014a. Depoliticizing land and water "grabs" in Colombia: The limits of Bonsucro certification for enhancing sustainable biofuel practices. Agriculture and Human Values 31 (2014), 455-468.

Smalley, R., 2013. Plantations, Contract Farming and Commercial Farming Areas in Africa: A Comparative Review. Land and Agricultural Commercialisation in Africa (LACA) Working Paper 55. Future Agricultures Consortium, Sussex.

Stirling, A., 2010. Keep it complex. Nature 468 (29-30), 1029-1031.

Sutcliff, S., Court, J., 2005. Evidence-Based Policymaking: What is it? How does it work? What relevance for developing countries? London: Overseas Development Institute.

Thondhlana, G., 2015. Land acquisition for and local livelihood implications of biofuel development in Zimbabwe. Land Use Policy 49, 11-19.

Tilman, D., Cassman, K. G., Matson, P. A., Naylor, R., Polasky, S., 2002. Agricultural sustainability and intensive production practices. Nature 418 (6898), 671-677.

Tilman, D., Socolow, R., Foley, J.A., Hill, J., Larson, E., Lynd, L., Pacala, S., Reilly, J., Searchinger, T., Somerville, C., Williams, R., 2009. Beneficial biofuels: The food, energy, and environment trilemma. Science 325 (2009), 270-271.

Trent, T. R., Chavis, D. M., 2009. Scope, scale, and sustainability: What it takes to create lasting community change. The Foundation Review 1 (1), 8.

UNEP, 2008. Green Jobs: Towards decent work in a sustainable, low-carbon world. UNEP/ILO/IOE/ITUC.

Vogel, I., 2012. Review of the use of 'Theory of Change' in international development. Review commissioned by the UK Department for International Development.

https://assets.publishing.service.gov.uk/media/57a08a5ded915d3cfd00071a/DFID ToC Revie w VogelV7.pdf (accessed 15.11.2016).

Vogelpohl, T., 2014. "Das ist wettbewerb. Und das ist normaler strukturwandel." Die neoliberalisierung der Deutschen biokraftstoffpolitik, in: Hirschl, B., Dietz, K., Vogelpohl, T., Dunkelberg, E., Backhouse, M., Herrmann, R., Brüntrup, M., (Eds.), Biokraftstoffe zwischen Sackgasse und Energiewende. Sozial-ökologische und transnationale Perspektiven. Oekom, München, pp. 15-39. 
Final approved version of manuscript published in 2017 in Energy Policy. For final published manuscript, please see: http://dx.doi.org/10.1016/j.enpol.2017.04.013

Von Geibler, J., 2013. Market-based governance for sustainability in value chains: Conditions for successful standard setting in the palm oil sector. Journal of Cleaner Production 56 (2013), 39-

53.

Walley, C.J., 2004. Rough Waters: Nature and Development in an East African Marine Park. Princeton University Press, Princeton, NJ.

Wilbanks, T.J., 2007. Scale and sustainability. Climate Policy 7, 278-287.

Wise, T.A., Cole, E., 2015. Mandating food insecurity: The global impacts of rising biofuel mandates and targets. Working Paper No. 15-01 (February). Global Development and Environment Institute, Medford.

Wollenberg, E., with Edmunds, D., Buck, L., 2000. Anticipating Change: Scenarios as a Tool for Adaptive Forest Management. Center for International Forestry Research, Bogor.

World Bank, 2010. Environmental, economic and social impacts of oil palm in Indonesia: a synthesis of opportunities and challenges. World Bank, Washington, D.C.

\footnotetext{
'See: http://www4.unfccc.int/submissions/indc/Submission\%20Pages/submissions.aspx; http://biofuelsnews.com/display news/10886/india sets out 2022 plan to beef up biofuels production/; http://www.fas.usda.gov/commodities/biofuels (accessed Oct 10, 2016).

ii If learning and governance are to be truly democratized in contexts of unequal knowledge and power, Miller and Erickson (2006) argue that an explicitly political approach to bridge scales and epistemologies is also needed. They identify several important ingredients to such an approach: building critical capacity for policy reasoning among diverse actors; promoting epistemic tolerance and pluralism; enhancing epistemic dialogue and exchange; and appropriately delegating authority across scales of governance.
} 